\title{
Tanggapan Alkitab dan Gereja Terhadap Faktor Pemicu Terjadinya Perceraian
}

\author{
Ricu Sele \\ Sekolah Tinggi Teologi Happy Family Surabaya \\ Korespondensi: selegideon777@gmail.com \\ Soelistiyo Daniel Zacheus \\ Sekolah Tinggi Teologi Cianjur \\ dennyzacheus24@gmail.com
}

\begin{abstract}
The divorce rate in Indonesia is increasingly showing a significant upward trend. Therefore, this study aims to describe the factors of divorce, the response of Lakit and the church to the divorce. Divorce doesn't just happen. Divorce is triggered by various factors. These factors are used as justification for conducting a divorce. Those reasons are used as the basis for suing and carrying out a divorce. The Bible is against divorce. God hates divorce. God never designed a marriage for divorce. Biblical marriage is marriage for life. Marriage must be built on a strong foundation, namely love. Like the bond of love between Christ and His church, so is the bond of husband and wife in a marriage. The church is in line with the Bible / Word of God, does not tolerate divorce. The church must strive to prevent its people from divorcing. Because divorce does not solve problems, but in Christ and His love all problems that arise in marriage can be resolved. He is in Christ and in His love there must be a way out. The method used by researchers in this writing is descriptive qualitative by using literature sources that support the writing of this article. Hopefully the results of this research can be a reference for pastors and churches and people to solve every problem in marriage wisely so that it doesn't end in divorce.
\end{abstract}

Keywords: bible; church; divorce; husband; wife

\begin{abstract}
Abstrak
Angka perceraian di Indonesia semakin menunjuk tren peningkatan yang signifikan. Karena itu penelitian ini bertujuan untuk memaparkan faktor-faktor perceraian, tanggapan Alkitab dan gereja terhadap perceraian tersebut. Perceraian dipicu oleh berbagai faktor. Alasan-alasan itulah yang dijadikan sebagai dasar untuk menuntut dan melakukan perceraian. Alkitab menentang perceraian. Tuhan tidak pernah merancang sebuah pernikahan untuk perceraian. Pernikahan Alkitabiah adalah pernikahan seumur hidup. Pernikahan harus dibangun dasar yang kuat yaitu kasih. Seperti ikatan kasih antara Kristus dan jemaatNya. Gerejapun sejalan dengan Alkitab/Firman Allah, tidak mentolerir adanya perceraian. Gereja harus berjuang untuk menghindarkan umatnya dari perceraian. Sebab perceraian tidak menyelesaikan masalah, tetapi di dalam Kristus dan kasihNya semua persoalan yang muncul dalam pernikahan bisa diselesaikan. Adapun metode yang dipergunakan peneliti dalam penulisan ini adalah deskriptif kualitatif dengan menggunakan sumber-sumber literatur yang mendukung penulisan artikel ini. Kiranya hasil penelitian ini, dapat menjadi acuan bagi Pendeta dan gereja serta umat untuk menyelesaikan setiap masalah dalam pernikahan secara bijak sehingga tidak berakhir dengan perceraian.
\end{abstract}

Kata Kunci: alkitab; gereja; perceraian; suami; istri 


\section{Pendahuluan}

Tingkat perceraian di Indonesia cukup tinggi. Angka perceraian suami dan istri di Indonesia kian meningkat dari tahun ke tahun. Kasus penceraian telah menjadi topik yang tidak pernah habis-habisannya di bicarakan dipublik baik di kalangan masyarakat biasa, artis) maupun di kalangan gereja (orang percaya). Fenomena penceraian saat ini telah menjadi perhatian semua kalangan dan juga telah menjadi pokok persoalan yang berkepanjangan dalam hidup setiap orang. Angka perceraian di Indonesia menunjukkan tren pengingkatan yang signifikan. Hidayat mengatakan, dalam jangka waktu tiga terakhir (2015-2017) jumlah perkara putusan (inkracht) perceraian di Pengadilan Agama seluruh Indonesia terjadi/mengalami peningkatan. Misalnya, angka perkara pengajuan cerai talak (suami) dan cerai gugat (istri) di 29 Pengadilan Tinggi Agama pada tahun 2015 tercatat totalnya sebanyak 394.246 perkara (cerai talak: 113.068 dan cerai gugat: 281.178 perkara) dan yang diputuskan sejumlah 353.843 perkara (cerai talak: 99.981 dan cerai gugat: 253.862 perkara). ${ }^{\text {Semakin jauh }}$ sebuah keluarga berjalan, maka semakin luas pula interaksi yang dibangun dengan masyarakat yang menjadi lingkungannya.

Kondisi ini bisa berdampak baik, sekaligus bisa berdampak buruk terhadap eksistensi keluarga dan anggota-anggotanya. Dampak yang buruk adalah terjadinya disintegrasi, miskomunikasi, pertengkaran, kekerasan dalam rumah tangga, dan yang paling final adalah terjadinya perceraian. Jayani mengatakan, tren perceraian di Indonesia semakin meningkat setiap tahunnya. Pada 2018, angka perceraian Indonesia mencapai 408.202 kasus, meningkat 9\% dibandingkan tahun sebelumnya. Penyebab terbesar perceraian pada 2018 adalah perselisihan dan pertengkaran terus menerus dengan 183.085 kasus. Faktor ekonomi menempati urutan kedua sebanyak 110.909 kasus. Sementara masalah lainnya adalah suami/istri pergi $(17,55 \%)$, KDRT $(2,15 \%)$, dan mabuk $(0,85 \%) .{ }^{2}$ Sampai saat ini tidak ada data yang akurat berapa nilai korban yang timbul dari kekacauan keluarga tersebut di atas, kecuali data perceraian atau kematian. Perceraian adalah sebuah kata yang tidak pernah menjadi citacita dari sebuah keluarga atau pernikahan.

Tidak ada seorangpun yang menginginkan terjadinya perceraian. Tetapi hal-hal tertentu bisa menjadi pemicu terjadinya perceraian tersebut. Matondang mengungkapkan, pada umumnya hal/faktor yang menyebabkan terjadinya perceraian sangat unik dan kompleks dan tiap-tiap keluarga berbeda satu dengan lainnya. ${ }^{3}$ Penyebab terjadinya perceraian antara lain: ketidakcocokan atau ketidakharmonisan, kesalahan dalam berkomunikasi, masalah ekonomi (finansial), masalah kekerasan dalam rumah tangga, ketidaksetiaan, konflik peran, masalah seksual dan juga hadirnya orang ketiga sebagai efek dari pergaulan melalui media sosial. Kiranya hasil penelitian ini dapat memberi gambaran bagi negara, gereja, keluarga untuk mengenali sejak dini faktor-faktor yang bisa menjadi pemicu terjadinya perceraian. Selanjutnya dapat mengambil langkah-langkah bijak dan sesuai dengan ajaran Alkitab dalam menyelesaikan setiap konflik dalam rumah tangga. Bagi pasangan pra-nikah untuk mempersiapkan diri dengan baik sebelum memutuskan untuk memasuki jenjang yang lebis serius yaitu pernikahan.

\section{(2018).}

${ }^{1}$ Rofiq Hidayat, "Melihat-Tren-Perceraian-Dan-Dominasi-Penyebabnya," hukumonline 4

2 Dwi Hadya Jayani, “Ramai-Ruu-Ketahanan-Keluarga-Berapa-Angka-Perceraian-DiIndonesia," https://databoks.katadata.co.id (2018).

${ }^{3}$ Armansyah Matondang, "Faktor-Faktor Yang Mengakibatkan Perceraian Dalam Perkawinan," JPPUMA: Jurnal Ilmu Pemerintahan dan Sosial Politik UMA (Journal of Governance and Political Social UMA) 2, no. 2 (2014): 143. 


\section{Metode Penelitian}

Dalam rangka mendapatkan data dan informasi yang dapat dipertanggungjawabkan, maka diperlukan penelitian terhadap satu pokok materi yang sedang dibahas. Mulyana menjelaskan, metode adalah proses, prinsip dan prosedur yang digunakan untuk suatu pendekatan dalam mengkaji topik penelitian hingga mencari jawaban. ${ }^{4}$ Sedangkan menurut Noor, metode dapat dirumuskan sebagai suatu proses atau prosedur yang sistimatik berdasarkan prinsip dan teknik ilmiah yang dipakai oleh disiplin (ilmu) untuk mencapai suatu tujuan. ${ }^{5}$ Maka dalam penulisan artikel ini, peneliti menggunakan metode deskriptif kualitatif. Peneliti mempergunakan sumber-sumber literatur-literatur yang berkenaan dengan penelitian ini untuk memperkaya peneliti dalam mendapatkan informasi/data tentang penelitian dimaksud. Saluchu menjelaskan, pendekatan kualitatif lebih mengarah pada penyelidikan kebenaran yang bersifat relatif, hermenetik dan interpretatif. Pilihan pada pendekatan ini lebih banyak menggunakan analisis teori, dan hermenetik yang kuat untuk sampai pada sebuah kesimpulan. ${ }^{6}$ Maka dalam penelitian ini, peneliti mengumpulkan dan menganalisis semua data yang telah diperoleh dalam rangka mencapai tujuan penulisan ini tentang tanggapan Alkitab dan gereja tentang faktor-faktor penyebab terjadinya perceraian. Penelitian merupakan sebuah kajian literatur dengan pendekatan kualitatif yang menggunakan metode analisis deskriptif pada faktor-faktor penyebab perceraian.

\section{Hasil dan Pembahasan \\ Faktor-Faktor Pemicu Perceraian}

Jika diperhatikan dengan sungguh-sungguh, maka sebenarnya pernikahan berawal dari perjanjian antara seorang pria dan wanita untuk mengikatkan hubungan cinta kasih mereka dalam ikatan yang sah baik secara agama maupun secara hukum. Namun sayangnya bahwa niat itu terkadang tidak sesuai dengan kenyataan. Perceraian tidak terjadi begitu saja, tentu diawali dengan gejala-gejala yang kemudian menjadi faktor pemicu terjadinya perceraian. Ada banyak hal yang bisa menjadi pemicu terjadinya perceraian tersebut. Matondang mengatakan, perbedaan pendapat, perselisihan yang dibiarkan terus menerus dapat menyebabkan hilangnya perasaan cinta dan kasih sayang. Pertengkaran menyebabkan timbulnya rasa benci dan prasangka buruk atau kecurigaan terhadap pasangan. Keadaan tersebut dapat menyebabkan hilangnya rasa percaya dan menyebabkan terjadinya perceraian. Faktor terjadinya perceraian juga dapat dipicu oleh karena pernikahan di bawah umur. Pernikahan di bawah umur rawan dengan pertengkaran dan perceraian hal ini disebabkan karena mereka belum siap menghadapi dan mengatasi bentuk-bentuk pertikaian yang mereka jumpai. ${ }^{7}$ Berikutnya ini peneliti menyebutkan beberapa hal yang umumnya menjadi pemicu terjadinya sebuah perceraian.

Pertama, keuangan/ekonomi. Kebutuhan ekonomi adalah hal yang tidak bisa dihindari dalam sebuah keluarga. Setiap anggota keluarga memiliki kebutuhan ekonominya masing-masing. Kegagalan dalam mencukupi kebutuhan ekonomi keluarga bisa menjadi pemicu pertengkaran yang akhirnya bisa berakhir dengan perceraian. Matondang menguraikan, perceraian karena faktor ekonomi bukan semata-mata disebabkan karena suami tidak mampu memenuhi kebutuhan rumah tangga, tetapi bisa juga karena sang istri tidak bisa mengelolah ekonomi keluarga dengan baik. Tingkat kebutuhan ekonomi dan pemenuhannya di kondisi dewasa ini memaksa kedua pasangan untuk bekerja keras demi

4 Dedy Mulyana, Metode Penelitian (Bandung: Rosdakarya, 2002), 120.

${ }^{5}$ Juliansyah Noor, Metode Penelitian (Jakarta: Kencana Prenada Media Group, 2012 ), 76.

${ }^{6}$ Sonny Eli Zaluchu, "Strategi Penelitian Kualitatif Dan Kuantitatif Di Dalam Penelitian

Agama," Evangelikal: Jurnal Teologi Injili dan Pembinaan Warga Jemaat 4, no. 1 (2020): 32.

${ }^{7}$ Matondang, "Faktor-Faktor Yang Mengakibatkan Perceraian Dalam Perkawinan." 
memenuhi dan mencukupi kebutuhan ekonomi keluarga. Dengan pekerjaan dan hasil yang berbeda, seringkali menjadi sumber perselisihan yang hebat. Apalagi jika salah satu pasangan tidak bekerja. ${ }^{8}$

Ekonomi sebagai alasan perceraian sebenarnya adalah masalah klasik. Persoalan kecukupan ekonomi atau tanggung jawab ekonomi dari salah satu pihak terkadang dijadikan alasan sebagai penyebab perceraian. Dalam hal ini yang dimaksud perceraian karena faktor ekonomi adalah masalah nafkah keluarga, diantara mereka terdapat suami yang tidak bertanggung jawab terhadap kebutuhan keluarganya dan tidak bekerja keras untuk memenuhi kewajibannya. Terdapat pula diantara suami yang sebenarnya bertanggung jawab dan tetap berusaha memberikan nafkah, akan tetapi istrinya bergaya hidup mewah sehingga ia menuntut nafkah yang tidak bisa dipenuhi oleh suaminya dan kemudian mengajukan perceraian. Kurangnya keterbukaan atau transparansi antara masing-masing pasangan bisa menjadi pemicu pertengkaran yang bisa saja berujung pada perceraian. Pieloor mengatakan, bila anda sudah menikan berarti tidak ada lagi privasi diri, tidak ada lagi hal yang tabu dan tidak ada lagi hal yang tersembunyi di hadapan pasangan anda. Anda benar-benar "telanjang" luar dan dalam, jiwa dan raga, termasuk masalah penting yaitu uang dan ekonomi. Suami istri harus memiliki komunikasi yang transparan tentang segala hal yang berhubungan dengan ekonomi atau uang, jika tidak maka potensi kecuriagaan, pertengkaran dan perceraian sangat besar terjadi. Sekecil apapun sebuah pengeluaran atau hal-hal yang ada kaitannya dengan ekonomi keluarga, perlu untuk saling memberi informasi. ${ }^{9}$ Tidak dapat dipungkiri juga, terkadang penghasilan salah satu pasangan, entah lebih banyak atau lebih sedikit, bisa berpotensi menjadi sumber/pemicu pertengkaran, kecurigaan yang bisa mengakibatkan terjadinya perpisahan/perceraian.

Kedua, masalah seks. Tidak dapat dipungkiri bahwa suami istri yang masuk ke dalam rumah tangga tersebut, membawa kebutuhannya masing-masing termasuk di dalamnya adalah kebutuhan seks. Pemenuhan kebutuhan tersebut tentu bisa menjadi sumber masalah jika tidak sesuai dengan yang diharapkan oleh masing-masing pasangan. Seks memang penting bagi pernikahan yang sehat. Bagi istri, kepuasan seks dan kepuasan perkawinan menjadi faktor yang mempengaruhi tingkat perceraian. Kepuasan yang tinggi terhadap seks dan dalam relasi dengan suami membuat para istri cenderung tidak ingin bercerai. Tetapi tidak demikian halnya dengan suami. Kepuasan seks bagi suami merupakan faktor penting, yang bisa mengurangi tingkat perceraian. Dengan kata lain, kepuasan seks yang tinggi akan mengurangi keinginan pria untuk bercerai. Maka kedua pasangan bersama-sama harus saling meperhatikan kebutuhan masing-masing termasuk kebutuhan seks. Beberapa hal yang berkaitan dengan seks yang bisa menjadi faktor pemicu perceraian. Harjianto mengungkapkan, bahwa ada banyak hal yang menyebabkan terjadinya perselingkuhan misalnya: 1) adanya kesempatan; 2) perselisihan/konflik dengan istri; 3) masalah seks tidak terpuaskan; 4) abnormalitas atau animalistis seks; 5) iman yang rapuh; 6) karena hilangnya rasa/budaya malu. ${ }^{10}$ Bahwa seks atau kebutuhan biologis adalah juga menjadi hal yang signifikan pengaruhnya terhadap terjadinya sebuah perceraian.

Sementara itu, Alexander mengatakan dalam penelitannya bahwa keluarga/rumah tangga yang orientasinya adalah seks, maka rusaklah rumah tangga itu. Karena orientasinya itu, maka jika tujuannnya tidak tercapai, maka kecurigaan mulai muncul. Pernikahan harus

8 Ibid.

${ }^{9}$ Freddy Pieloor, Money, Love and Marriage (Jakarta: PT Elex Media Kamputindo, 2013), 177.

${ }^{10}$ Harjianto Harjianto and Roudhotul Jannah, "Identifikasi Faktor Penyebab Perceraian Sebagai Dasar Konsep Pendidikan Pranikah Di Kabupaten Banyuwangi," Jurnal Ilmiah Universitas Batanghari Jambi 19, no. 1 (2019): 35. 
dibangun di atas dasar yang lebih dari hanya sekedar kebutuhan seks atau orientasi seks.11 Pernikahan harus dibangun di atas dasar cinta kasih yang tulus. Tentu masih banyak hal yang berkaitan dengan seks sebagai potensi penyebab perceraian, tetapi peneliti hanya membatasi untuk membahas sesuai dengan penyajian seperti tersebut di atas.

Ketiga, mis-komunikasi. Suami istri terkadang terjebak di dalam komunikasi yang kurang berkualitas baik dari segi kuantitas maupun kualitas. Tuntutan kebutuhan ataupun rutinitas lainnya dapat menyebabkan terjadinya mis-komunikasi di antara suami istri. Tim LaHaye mengatakan, kurangnya komunikasi hampir selalu merupakan persoalan bagi suami istri. Bila bukan karena kekurangan komunikasi, maka yang menjadi persoalan adalah komunikasi yang salah. Kualitas dan kuantitas komunikasi dalam rumah tangga khususnya antara seorang suami terhadap istrinya ataupun sebaliknya, memegang peran yang sangat penting dalam menentukan kualitas dari sebuah pernikahan atau perkawinan. ${ }^{12}$ Borrong memiliki pendapat yang hampir sama tentang pentingnya komunikasi dalam hubungan suami istri, keharmonisan dan kebahagiaan dalam pernikahan sangat bergantung kepada komunikasi suami istri. Kesibukan yang menyita banyak waktu di luar rumah cenderung menghambat dan memacetkan komunikasi verbal suami istri. ${ }^{13}$ Memang tidak dapat dipungkiri bahwa desakan kebutuhan keluarga atau tingginya standar kebutuhan keluarga, dapat membuat suami istri menjadi sama-sama sibuk sehingga komunikasi diantara mereka menjadi berkurang. Suami istri perlu mengenali penghambat menurunnya kualitas komunikasi di antara mereka. Hal ini dimaksudkan untuk menghindarkan mereka dari situasi yang menjebak sehingga rumah tangga mereka mengalami kesulitan dalam membina komunikasi yang baik dan berkualitas.

Sementara itu, Trisna mengatakan, dalam pernikahan-pernikahan yang diambang kehancuran yang sangat terasa antara suami/istri itu ialah tidak adanya komunikasi yang baik antara mereka berdua. Komunikasi yang tidak berjalan baik diantara suami istri jelas dapat menjadi pemicu terjadi keretakan di dalam rumah tangga. ${ }^{14}$ Keretakan tersebut jika tidak cepat diselesaikan maka akan membawa konflik yang lebih panjang dan dalam yang pada akhirnya akan menjadikan pernikahan itu bubar di tengah jalan.

Keempat, kekerasan dalam Rumah Tangga. Undang-Undang No 23 tahun 2004 pasal 1 ayat 1 memberikan defenisi tentang kekerasan dalam rumah tangga, yaitu setiap perbuatan terhadap seseorang terutama perempuan, yang berakibat timbulnya kesengsaraan atau penderitaan secara fisik, seksual, psikologis, dan/atau penelantaran rumah tangga termasuk ancaman untuk melakukan perbuatan, pemaksaan, atau perampasan kemerdekaan secara melawan hukum dalam lingkup rumah tangga. Tentu yang dimaksud dengan rumah tangga adalah setiap orang yang hadir di dalam sebuah keluarga. Kekerasan yang dimaksud antara lain; kekerasan fisik, kekerasan psikhis, kekerasan seksual dan penelantaran rumah tangga. Ada juga sering ditemukan terjadinya kekerasan gender, biasanya dialami oleh perempuan. Hal ini disebabkan karena terkadang seorang suami merasa sebagai kepala yang berkuasa atas rumah tangga. Septiningsih mengatakan, pada penelitian tentang KDRT, ditemukan bahwa perempuan (istri) lebih sering menjadi korban kekerasan oleh pasangannya. ${ }^{15}$ Informasi mengenai kekerasan dalam rumah tangga sangat mudah ditemukan dalam kehidupan

${ }^{11}$ Alexander Christanday, Komunikasi Kristen (Yogyakarta: Yayasan Andi Offsett, 2015), 03.

12 Tim LaHaye, Kebahagiaan Pernikahan Kristen (Jakarta: BPK Gunung Mulia, 2011), 120.

${ }^{13}$ Robert P Borrong, Etika Seksual Kontemporer (Bandung: Ink Media, 2006), 73.

14 Jonathan A. Trisna, Pernikahan Kristen Suatu Usaha Dalam Kristus (Bandung: Kalam Hidup, 1987), 100.

${ }^{15}$ Dyah Siti Septiningsih and Nur'aeni, "Education for Family Wellness": Sebuah Upaya Prevensi Terjadinya Konflik Perkawinan, Kekerasan Dalam Rumah Tangga (Kdrt) Dan Perceraian," Prosiding Seminar Nasional Penelitian dan PKM Sosial, Ekonomi dan Humaniora Vol 4 (2014). 
masyarakat sehari-hari. Media-media memberikan informasi yang begitu massif tetang hal tersebut. Segala bentuk tindakan kekerasan tersebut yang terjadi antara suami istri dapat menjadi pemicu terjadinya perceraian atau bubarnya sebuah perkawinan. Ancaman, luka, dan tekanan yang berlangsung lama dapat menyebabkan korbannya tidak dapat menahan diri untuk menyelamatkan dirinya. Salah satu bentuk penyelamatan diri dari kekerasan dalam rumah tangga adalah si korban meminta atau menempuh jalur perceraian.

Kelima, kehadiran pihak ketiga. Sebuah pernikahan tidak hanya melibatkan suami istri saja, tetapi juga orang-orang lain yang ada di sekitar suami istri tersebut. Kehadiran orang lain tersebut bisa disebut sebagai pihak ketiga. Mereka berpotensi untuk menimbulkan dampak negatif terhadap sebuah pernikahan disamping dampak positifnya. Manurung mengungkapkan, faktor yang menyebabkan timbulnya konflik dalam keluarga yang mengakibatkan kegoncangan adalah dari suami istri itu sendiri atau pengaruh dari salah satu orang tua atau kedua belah pihak suami dan istri; pengaruh dari salah seorang anggota keluarga (anak-anak, orang yang menumpang di rumah termasuk keponakan dari salah seorang antara suami dan istri), atau mungkin pengaruh dari orang lain di luar keluarga. ${ }^{16}$

Kehadiran orang-orang tersebut tidak dapat dihindari karena mereka juga adalah bagian dari sebuah keluarga yang terlibat dalam pernikahan tersebut. Apabila kehadiran mereka tidak memberi dampak positif kepada sebuah pernikahan, maka yang terjadi adalah mereka menjadi sumber atau pemicu terjadinya konflik dalam rumah tangga yang akhirnya membawa keruntuhan dalam pernikahan tersebut. Tambunan mengatakan, penyelidikan menunjukkan bahwa penyelewengan terjadi sebagai akibat keretakan hubungan dan ketidaktentraman tinggal di rumah. Kemungkinan yang lain akan mendorong suami suka berkencan dengan wanita lain, dan istri yang ditinggal kesepian di rumah, juga ingin mencari pria lain teman kencan. ${ }^{17}$ Kehadiran orang ketiga sangat rentan membuat sebuah perkawinan berakhir dengan perceraian. Apalagi jika kehadiran orang tersebut baik laki-laki ataupun perempuan, dapat menjawab kekurangan yang dialami atau dirasakan oleh masing-masing pasangan selama menjalani sebuah pernikahan/perkawinan.

Keenam, pernikahan dini atau tanpa cinta. Hasanah mengatakan, pernikahan pada usia muda sangat mudah ditimpa masalah karena tingkat penguasaan emosi belum stabil. Dalam perkawinan akan dijumpai berbagai permasalahan yang menuntut kedewasaan dalam hal penanganannya.18 Dengan demikian, sebuah perkawinan tidak dipandang sebagai kesiapan materi belaka, tetapi juga kesiapan mental dan kedewasaan untuk mengarunginya. Pernikahan yang terjadi karena dorongan seks atau ketertarikan fisik semata-mata, adalah dasar yang sangat rapuh. Unit Perlindungan Anak dan Perempuan GOW Wonosobo dalam uraiannya menerangkan bahwa alasan lainnya yang kerap dikemukakan oleh suami dan istri untuk mengakhiri sebuah perkawinan adalah bahwa perkawinan mereka telah berlangsung tanpa dilandasi adanya cinta. ${ }^{19}$ Bahwa tidak dapat dipungkiri ada perkawinan yang tidak didasari atas cinta tetapi atas motif yang lain. Ketika motif itu terpenuhi maka suami istri yang terikat dalam perkawinan/pernikahan itu menenui kesulitan-kesulitan. Kehidupan rumah tangga yang dijalani oleh pasangan yang menikah tanpa saling mencintai berjalan hambar, tidak harmonis, bahkan diwarnai pertengkaran. Suami dan istri pun hanya menjalankan kewajiban sesuai dengan perannya dalam rumah tangga, suami bekerja mencari nafkah dan istri melayani suami. Setiawan mengatakan, sudah bukan rahasia lagi jika pada jaman dahulu

${ }_{16}$ M.R Manurung, Manajemen Keluarga (Bandung: Indonesia Publishing House, 1995), 64.

67.

${ }^{17}$ E. H Tambunan, Mengatasi Masalah Keluarga (Bandung: Indonesia Publishing House, 1998),

18 Uswatun Hasanah, "Pengaruh Perkawinan Usia Muda Pada Tingkat Perceraian Dini (Studi Kasus Pengadilan Agama Kisaran)," Journal of Science and Social Research 1, no. February (2018): 13-18.

19 Unipagow, "Faktor-Faktor Dan Dampak Perceraian.Htm," Unipagow.blog.spot.co.id (2013). 
banyak orang menikah tanpa dilandasi rasa cinta, seperti Siti Nurbaya dan R.A Kartini. ${ }^{20}$ Pernikahaan yang terjadi akibat paksaan, perjodohan atau alasan lain seringkali membuat mereka yang menjalani akhirnya hidup dalam tekanan dan tidak pernah bisa merasakan kebahagiaan.

Alasan lainnya yang kerap dikemukakan oleh suami dan istri, untuk mengakhiri sebuah perkawinan adalah bahwa perkawinan mereka telah berlangsung tanpa dilandasi adanya cinta. Setelah merasa kehidupan rumah tangga yang hambar dan selalu ada pertengkaran, sangat besar kemungkinan godaan dari luar untuk datang. Pernikahan pun menjadi goyah. Bisa saja pasangan menemukan orang lain atau mantan yang memberikan rasa cinta padanya. Walaupun tidak dipungkiri ada perkawinan tanpa landasan cinta yang bisa bertahan sampai salah satu pasangannya meninggal. Hal tersebut bisa terjadi karena adanya faktor-faktor penguat dalam ikatan tersebut misalnya: anak, kesehatan dan atau ekonomi, pandangan umum masyarakat.

\section{Pandangan Alkitab Tentang Perceraian}

Berdasarkan pembahasan sebelumnya bahwa ada beberapa faktor pemicu perceraian dalam keluarga yang menyebabkan runtuhnya sebuah pernikahan. Apapun alasan yang menjadi dasar untuk melakukan perceraian, Alkitab memiliki pandangan tersendiri tentang hal tersebut. Pada bagian ini penulis membahas bagaimana tanggapan Alkitab terhadap faktor perceraian yang ada. Alkitab adalah dasar hidup bagi setiap orang Kristen. Alkitab tidak memberikan definisi tentang perceraian. Tetapi dalam beberapa situasi ayat Alkitab memberikan penjelasan dan jawaban tentang perceraian tersebut. Para tokoh sentral seperti Nabi Musa, Tuhan Yesus, dan Rasul Paulus yang memberikan jawaban tentang perceraian yang dimaksud. Penulis hanya mengutip beberapa pandangan dari Perjanjian Lama dan Perjanjian Baru sebagai bentuk pandangan-pandangan Alkitab tentang perceraian.

\section{Perceraian Menurut Perjanjian Lama}

Pandangan Perjanjian lama tentang sebuah pernikahan atau perkawinan dapat jelas terlihat frase "Tidak baik, kalau manusia itu seorang diri saja, Aku akan menjadikan penolong baginya yang sepadan dengan dia (Kejadian 2:18)." Pernikahan atau perkawinan merupakan sebuah lembaga yang ditetapkan dan dibentuk oleh Tuhan sendiri bagi manusia sesuai dengan kebutuhannya. Bahkan lembaga bentukanNya itu kemudian diberkati (Kejadian 1:28). Perjanjian Lama sesungguhnya memberikan larangan terhadap perceraian. Walaupun dalam Ulangan 24:1-4 disana diatur tentang perceraian tetapi kemudian Tuhan Yesus mengatakan bahwa hal itu diberikan karena ketegaran hati umatNya. Verkuyl menjelaskan bahwa dalam Perjanjian Lamapun keteguhan (kekekalan, keawetan) pernikahan itu diterangkan sebagai tuntutan dan sebagai pemberian. Sungguhpun demikian, Alkitab mengatakan juga tentang borderline cases yakni soal-soal istimewa, yang biasanya sulit untuk memberi keputusannya, sehingga terpaksa mengadakan perceraian, sekalipun menyedihkan juga. ${ }^{21}$

Nabi Musa memang mengijinkan seorang suami memberikan surat cerai kepada istrinya, tetapi sekali lagi itu karena ketegaran/kekerasan hati umat Israel. Kekerasan hati manusia membuatnya sulit untuk mengampuni. Dari awalnya Tuhan tidak merancang perkawinan berakhir dengan cara bercerai. Bahkan dalam Kitab Maelakhi 2:16 dikatakan bahwa Tuhan sendiri membenci perceraian. Tentu umat Tuhan tidak diarahkan untuk melakukan apa yang dibenci oleh Tuhan. Gunawan mengungkapkan, perceraian itu diijinkan bukan diperintahkan, hal ini terjadi karena "sklerokardia" atau kekerasan hati manusia. Dosa membuat hati manusia mejadi keras. Kekerasan hati manusia mengakibatkannya sulit

20 Obaja Tanto Setiawan, Dahsyatnya Visi (Yogyakarta: Yayasan Andi Offsett, 2009), 23.

${ }^{21}$ J.Verkuyl, Etika Kristen: Seksuil (Jakarta: BPK Gunung Mulia, 1989), 113. 
mengampuni, menganggap diri benar, meremehkan Firman Tuhan, menutup diri terhadap koreksi, menolak untuk berubah, menyebabkan hubungan suami istri rusak, dan keluarga berantakan, bahkan perceraian. ${ }^{22}$

Perceraian bukan perintah Tuhan. Kekerasan hati manusialah yang membuat nabi Musa mengijinkannya. Dalam Kitab kejadian 2:24, ikatan perkawinan oleh Tuhan sendiri diberi istilah "menjadi satu daging." Ikatan perkawinan adalah ikatan persatuan. Dengan demikian tidak bisa dipisahkan. Demikianlah mereka bukan dua melainkan satu. Apa yang satu dimata Tuhan, akan tetap satu untuk selamanya. Lebih lanjut Gunawan mengatakan, pernikahan merupakan kovenan dan komitmen yang mengikat, bersifat permanen dan seumur hidup. Sebuah kovenan menurut Alkitab adalah sebuah hubungan yang sakral antara dua pihak, disaksikan oleh Allah, sangat mengikat, dan tidak dapat dibatalkan. Kedua belah pihak bersedia berjanji untuk menjalani kehidupan sesuai dengan butir-butir perjanjian itu. ${ }^{23}$ Pernikahan adalah sakral, Allah ikut terlibat di dalamnya. Pernikahan bersifat permanen dalam sebuah perjanjian yang mengikat. Kuatnya perjanjian itu karena Allah ikut menjadi saksinya. Maleakhi 2:14 mengatakan bahwa Tuhan telah menjadi saksi antara engkau dan istri mudamu yang kepadanya engkau telah tidak setia, padahal dialah teman sekutumu dan istri seperjanjianmu.

\section{Perceraian Menurut Perjanjian Baru}

Pandangan Perjanjian Baru tentang perceraian tentu tidak bertentangan dengan apa yang sudah ditegaskan di dalam Perjanjian Lama. Tuhan Yesus hanya menegaskan kembali bahwa perceraian diijinkan oleh nabi Musa karena ketegaran hati dari umat Israel (Matius 19:7-8). Lebih lanjut Verkuyl menjelaskan khotbah Tuhan Yesus tentang perceraian karena zinah: Yang dimaksud Tuhan Yesus di sini ialah suatu keadaan, di mana istri (atau suami) jatuh ke dalam dosa, tidak secara insidentil (kebetulan), tetapi si istri atau si suami hidup dan dengan tetap hidup dalam dosa zinah. Di situlah hancurnya dasar-dasar, pondamenpondamen pernikahan. Di situlah pernikahan telah rusak sama sekali, sehingga tidak dapat diperbaiki kembali dan jika sudah demikian keadaannya, perceraian tidak terlarang lagi. Sebab pada hakekatnya pernikahan sudah tidak ada lagi. ${ }^{24}$

Pandangan tersebut adalah pandangan secara etika. Tetapi secara teologis bahwa pernikahan Kristen adalah ikatan seumur hidup. Tuhan Yesus kembali mengutip pernyataan Perjanjian Lama bahwa "demikianlah keduanya menjadi satu daging" dan "apa yang dipersatukan Allah tidak boleh diceraikan manusia." (Matius 19:5-6). Henry menjelaskan, suami dan istri, yang dipersatukan oleh hukum Allah, tidak boleh diceraikan oleh hukum manusia manapun, karena Allah tidak pernah memberikan wewenang atas hal tersebut. 25 Sementara itu Peniel mengatakan, berdasarkan kitab Injil Matius, Markus, dan Lukas, bahwa mereka yang ada dalam perzinaan adalah suami yang menceraikan istrinya, maka ia membuat istrinya berzina; laki-laki yang kawin atau menikah dengan istri yang diceraikan oleh suaminya, laki-laki itu berbuat zina; dan suami yang menceraikan istrinya, lalu kemudian kawin dengan perempuan lain, maka suami tersebut berbuat zina; istri menceraikan suaminya dan menikah dengan laki-laki lain, maka ia berbuat zina. Hanya Tuhanlah yang berdaulat atas berakhirnya sebuah ikatan perkawinan atau pernikahan. Tidak ada hukum di dunia yang bisa

${ }^{22}$ Gunawan T. Samuel, "Artikel Sabda.Org/Perceraian Dan Pernikahan Kembali.," artikel sabda.org/perceraian dan pernikahan kembali (2017).

${ }^{23}$ Ibid.

${ }^{24}$ J.Verkuyl, Etika Kristen: Seksuil.

${ }^{25}$ Matthew Henry, Tafsiran Matthew Henry Injil Matius 15-28 (Surabaya: Momentum Press, 2008), 936. 
membatalkan ikatan tersebut. Siapapun manusia yang melakukannnya itu berarati ia melanggar hukum Allah. ${ }^{26}$

Paulus sebagai seorang rasul Tuhan juga tidak luput memberikan penjelasan tentang sebuah perceraian. Rasul Paulus dalam Kitab Roma 7:2-3 mengatakan: "Sebab seorang istri terikat oleh hukum kepada suaminya selama suaminya itu hidup. Akan tetapi apabila suaminya itu mati, bebaslah ia dari hukum yang mengikatnya kepada suaminya itu. Jadi selama suaminya hidup ia dianggap berzinah, kalau ia menjad istri laki-laki lain; tetapi jika suaminya telah mati, ia bebas dari hukum, sehingga ia bukanlah berzinah, kalau ia menjadi istri laki-laki lain." Barclay menjelaskan, pemikiran dasar dari bagian ini terdapat pada pribahasa hukum yang mengatakan, bahwa kematian membatalkan semua kontrak.27 Pernikahan Kristen adalah pernikahan seumur hidup. Jadi dari semula Allah menetapkan perkawinan sebagai ikatan seumur hidup. Sejak awal, Tuhan menetapkan perkawinan sebagai ikatan permanen yang akan berakhir hanya ketika salah satu dari pasangannya telah meninggal. Pernikahan menurut Alkitab adalah komitmen seumur hidup. Walaupun pernikahan kristen seumur hidup tetapi jelas bukan bersifat kekal.

\section{Tanggapan Alkitab Terhadap Faktor Perceraian}

Salsadila menerangkan, Alkitab sudah selayaknya menjadi panduan bagi umat Kristen dalam menjalani hidup. Di dalamnya juga sudah tertera beragam pemecahan persoalan hidup lengkap, seperti ayat Alkitab tentang suami selingkuh, ayat Alkitab tentang pengedar narkoba, ayat Alkitab tentang pengendalian diri dan yang lainnya. Semua orang memiliki persoalannya masing-masing, termasuk masalah dalam keluarga/pernikahan. ${ }^{28}$ Setiap orang Kristen wajib menjadikan Alkitab sebagai dasar dan standar dalam menyelesaikan setiap persoalan yang dihadapi. Khusus terhadap faktor-faktor pemicu terjadinya perceraian, berikut penulis akan menuliskan tanggapan Alkitab terhadap hal-hal tersebut.

\section{Tanggapan Alkitab Terhadap Faktor Ekonomi Sebagai Alasan Perceraian}

Dalam kaitannya dengan masalah ekonomi/keuangan, Alkitab memberikan penjelasan yang komplit sebagai solusi ataupun jalan keluarnya. Ada begitu banyak peristiwa-peristiwa di dalam Alkitab yang berkaitan dengan masalah ekonomi antara lain, Kisah tentang Elia di sungai Kerit (I Raja-raja 17:1-6, kisah tentang janda Sarfat (I Raja-raja 17:7-24). Widoyo mengatakan, tidak dapat dipungkiri bahwa dalam pelayaannya, Elia banyak menghadapi kesulitan dan rintangan. Antara lain mau dibunuh oleh Izebel. Elia sebagai manusia biasa juga sempat mengalami dan menjalani masa-masa yang sulit. Ia bersembunyi dari Izebel ke padang gurun. Tetapi Allah menunjukkan kuasaNya dan memelihara umatNya. Ia tidak pernah meninggalkan orang yang sudah dipilih-Nya, Elia diberi makan dengan cara yang ajaib. Akhirnya Elia mendapat kekuatan baru untuk menyelesaukan tugas dan tanggung jawabnya ( 1 raja-raja 19:1-8). ${ }^{29}$ Rasul Paulus mengatakan aku tahu apa itu kekurangan, apa itu kelebihan, dan sebagainya, tetapi segala perkara dapat ditanggung di dalam Tuhan yang memberi kekuatan kepadanya (Filipi 4:13). Jadi sesungguhnya persoalan keuangan/ekonomi tidaklah terlalu kuat untuk dijadikan sebagai alasan perceraian (faktor

97.

${ }^{26}$ Peniel C.D. Maiaweng, "Perceraian Dan Pernikahan Kembali," Jurnal Jaffray 15, no. 1 (2017): 2011), 142.

27 William Barclay, Pemahaman Alkitab Setiap Hari: Kitab Roma (Jakarta: BPK Gunung Mulia,

28 RA. Salsadilla, Mengatasi Masalah Dengan Mangatasi Masalah (Jakarta: CV Pranata Widya Sejahtera, 2020), 12.

${ }^{29}$ Hadi Widoyo, Christian Ade Maranatha, and Yohanis Ndapamuri, "KUASA ALLAH

DALAM ELIADAM IMPLIKASINYA BAGI UMAT TUHAN PADA MASA KINI," QUAERENS Vol.2, no. 1 (2020): 24. 
perceraian). Dari ayat di atas jelas bahwa Allah sanggup memelihara umatNya dengan caracaraNya sendiri.

\section{Tanggapan Alkitab Terhadap Faktor Seks Sebagai Alasan Perceraian}

Seks lahir bersama-sama dengan manusia. Seks itu suci. Jadi tidak ada yang salah dengan seks itu jika disalurkan pada dan dengan cara yang sesuai dengan firman Tuhan. Selanjutnya bahwa Alkitab memberikan istilah persatuan laki-laki dan perempuan sebagai "satu daging" (Kej 2:24-25). Dengan memandang seks sebagai sesuatu yang suci dan merupakan bagian dari ciptaan Tuhan, maka hendaknya suami istri dapat menyalurkan dorongan-dorongan seks itu dengan tidak melanggar aturan-aturan Firman Tuhan. Lalu bagaimana jika salah satu pasangan melakukan kesalahan atau penyimpangan atau penyelewengan seks? Alkitab menerangkan bahwa Apa yang dipersatukan oleh Allah tidak boleh diceraikan manusia (Mark 10:9), dan ada perintah Tuhan untuk saling mengampuni, bahkan tujuh puluh kali tujuh kali (Mat 18:22). Antonius mengatakan, seorang laki-laki menikahi seorang perempuan merupakan pola pernikahan yang diterapkan sekaligus dikehendaki Allah. Alkitab tidak membenarkan suami istri menyalahgunakan hak istimewa tentang kasih seksual yang menjadi bagian yang normal dalam pernikahan. Tubuh istri adalah sudah menjadi milik suaminya, dan tubuh suami adalah sudah menjadi milik istrinya: masing-masing harus penuh perhatian dan hormat terhadap pasangannya. ${ }^{30}$ Sesungguhnya Alkitab sudah memberikan batasan-batasan dan petunjuk bagaimana suami istri dalam sebuah pernikahan memperhatikan dan melayani pasangannya. Dengan jelas Alkitab memberikan aturan untuk suami istri menyalurkan dorongan-dorongan seks dan kegiatan seks mereka sebagai suami istri.

\section{Tanggapan Alkitab Terhadap Faktor Miskomunikasi Sebagai Alasan Perceraian}

Christanday memberikan padangannya tentang langkah-langkah komunikasi Kristen adalah "kita menerima Kristus, Kristus menerima kita, kita menerima dan mengalami kasihNya, kita menerima diri kita sendiri, dan kita menerima serta mengasihi orang lain." Dengan demikian, terciptalah komunikasi Kristen yang baik. ${ }^{31}$ Komunikasi Kristen adalah komunikasi yang dibangun atas dasar kasih Kristus yang mulia dan suci. Kolose 4:6 mengatakan bahwa hendaklah kata-katamu senantiasa penuh kasih. Artinya komunikasi yang dibangun dalam rumah tangga Kristen adalah komunikasi yang penuh dengan kasih. Bukankah kasih itu panjang sabar, kasih itu murah hati, kasih itu lemah lembut, kasi itu tidak mencari kepentingan diri sendiri. Kasih menutupi pelanggaran. Kasih harus rela berkorban. Rela untuk mendengar. Keluarga harus dibangun atas komitmen yang kuat, cinta kasih yang tulus bukan hanya sekedar ketertarikan fisik atau lainnya. Dengan demikian, setiap komunikasi dari orang-orang yang percaya kepada Kristus, harus mendasarkannya pada kasih Kristus. Sebagaimana Kristus menyapa jemaatNya. Sebagaimana Kristus mengasihi jemaatNya demikianlah hendaknya komunikasi yang terbangun dalam keluarga Kristen. Dengan demikian perceraian karena mis-komunikasi dapat dihindarkan. Kunci sukses sebuah pernikahan/perkawinan/rumah tangga adalah komunikasi yang tuntas dan efektif yang dibangun atas kasih yang tulus seperti kasih Kristus kepada jemaat.

${ }^{30}$ Seri Antonius, "Pernikahan Kristen Dalam Perspektif Firman Tuhan," Jurnal Pionir LPPM Universitas Asahan 6, no. 2 (2020).

${ }^{31}$ Andreas Christanday, Komunikasi Dalam Keluarga Kristen (Yogyakarta: Andi Offsett, 2015), 03. 


\section{Tanggapan Alkitab Terhadap Faktor Kekerasan Dalam Rumah Tangga (KDRT)}

Ndruru mengatakan bahwa sesungguhnya apa yang disebut kekerasan dalam rumah tangga tidak akan pernah terjadi apabila masing-masing pasangan menanamkan konsep kasih dalam keluarga tersebut dan melandasinya dengan sebuah komitmen untuk takut akan Tuhan. Segala bentuk kekerasan dalam rumah tangga apapun alasannya adalah bertentangan dengan kebenaran Firman Tuhan. ${ }^{32}$ Aloysius mengutip Efesus 5:22-23 mengatakan, suami istri dapat bertahan dalam membangun hidup keluarga sekaligus terhindar dari tindakan kekerasan bila masing-masing pihak mampu menahan diri terhadap emosi, mampu mengolah hidup batin, dan rela memberikan diri atas dasar cinta yang dihidupi. Cinta Kristus terhadap gereja/jemaat merupakan acuan kehidupan suami-istri di dalam keluarga Kristen. Suami istri membangun keluarganya dengan cinta kasih, jauh dari kekerasan dalam bentuk apapun. ${ }^{33}$ Kekerasan yang terjadi di dalam rumah tangga tentu sangat bertentangan dengan rencana Allah bagi keluarga. Dalam Kitab Kejadian 1 dan 2 Tuhan memberi gamabaran tentang pernikahan dengan sebutan sebagai satu daging, sebagai satu hubungan yang saling membantu. Kitab Efesus pasal 5:21 meminta kepada suami istri untuk saling merendahkan diri seorang kepada yang lain. Kitab Efesus 5:22-24 mengajarkan istri agar tunduk kepada suaminya, sementara ayat 25-33 berbicara tentang kasih yang rela berkorban dari seorang suami bagi istrinya.

Peristiwa kekerasan dalam rumah tangga sama saja melawan/menentang dan tidak mengindahkan apa yang sudah diajarkan Tuhan Yesus kepada melalui firman Nya. Ajaran yang diberikan Tuhan Yesus jelas memerintahkan untuk saling mengasihi satu sama lain terlebih dalam anggota keluarga. Pada dasarnya kekerasan dalam rumah tangga tidak akan pernah terjadi apabila setiap anggota keluarga menanamkan kasih dalam keluarga tersebut dan melandasi sebuah keluarga tersebut dengan komitmen untuk takut akan Tuhan.

\section{Pandangan Alkitab Terhadap Kehadiran Pihak Ketiga Sebagai Alasan Perceraian}

Jika ditelaah dengan seksama, apa yang terdapat dalam Kejadian 2:24 dikatakan bahwa apabila pasangan telah disatukan dalam hubungan pernikahan, itu artinya mereka telah menjadi satu daging dan tidak dapat dipisahkan oleh apapun kecuali maut. Maka sesungguhnya tidak ada tempat untuk orang ketiga dalam sebuah pernikahan Kristen. Mereka adalah satu, dan persatuan yang dimaksud adalah persatuan yang erat melakat tidak ada celah. Sebab pernikahan hanya terjadi dan terdiri dari satu laki-laki (suami) dan satu perempuan (isteri) dan pernikahan tidak mengenal oknum ketiga. Dalam 1 Korintus 7:4 dikatakan bahwa istri tidak berkuasa atas tubuhnya sendiri, tetapi suaminya. Dan begitu pula sebaliknya, suami juga tidak berkuasa atas tubuhnya sendiri, tetapi istrinya. Setelah laki-laki dan perempuan menikah, itu artinya mereka telah memutuskan hak khusus atas tubuhnya sendiri dan memberikan hak tersebut kepada pasangannya. Jadi, ayat ini mengajarkan para pasangan yang sudah menikah bahwa mereka tidak lagi memiliki tubuhnya sendiri, melainkan tubuhnya juga milik pasangannya. Jadi yang boleh memakai tubuhnya hanyalah pasangannya sendiri, dan bukan orang lain.

Dalam Ibrani 13:4, Allah memerintahkan manusia untuk menghormati perkawinan dan jangan mencemarkan tempat tidur dengan perbuatan zinah. Karena pernikahan adalah persekutuan hidup dan lembaga terhormat yang dirancang oleh Allah untuk manusia. Dan Allah akan menghakimi siapa saja yang mengotori hubungan perkawinan dengan berbuat zinah. Di dalam ikatan pernikahan, setiap suami dan isteri telah melepaskan hak khusus atas

\footnotetext{
${ }^{32}$ Steven Anugerah Jaya Ndruru, “Pernikahan Kudus, KDRT Dan Perceraian Dalam Gereja Masa Kini," OSFPREPRINTS 1 (2020).

${ }^{33}$ Aloysius Lerebulan, Keluarga Kristiani, Antara Idealisme Dan Tantangan (Yogyakarta: Kanisius, 2016), 136.
} 
tubuhnya sendiri dan memberikan hak itu kepada pasangannya. Tidak seorangpun dalam ikatan pernikahan melalaikan untuk memenuhi hasrat seksual yang normal dari pasangannya, melalaikan atau menolak kewajiban tersebut maka suami dan istri telah membuka peluang untuk hidup dalam perzinahan atau perselingkuhan. Kecuali atas persetujuan bersama untuk sementara waktu suami dan isteri menjauhkan diri, Paulus menegaskan supaya hal itu dilakukan untuk menjadi kesempatan suami dan isteri berdoa (I Kor.7:5).

Perceraian suami istri atau paing tidak kekacauan dalam rumah tangga dapat dipicu oleh kemajuan tekhnologi khususnya alat komunikasi. Seperti yang disampaikan oleh Arsyad, dalam rumah tangga, pengaruh negatif media sosial ternyata dapat menyebabkan ketidakharmonisan dalam sebuah keluarga dan dapat berujung pada perceraian. Meskipun, media sosial tidak menjadi alasan langsung terhadap terjadinya sebuah perceraian, namun penggunaan media sosial dengan cara yang menyimpang merupakan faktor eksternal yang dapat memicu terjadinya perselisihan antara suami dan istri. ${ }^{34}$ Kemajuan teknologi adalah kegenapan Firman Tuhan. Dan Suami istri tidak dapat menghindari hal tersebut. Tetapi perlu diketahui bahwa pengetahuan diberikan oleh Tuhan untuk memuliakan namaNya di bumi. Kemajuan teknologi informasi tidak lalu memberi ruang bagi hadirnya pihak ketiga dalam sebuah pernikahan.

\section{Pandangan Alkitab Terhadap Pernikahan Dini}

Menurut pandangan Kristen, pernikahan bukan hanya sekadar euforia cinta di masa muda saja. Tapi pernikahan harusnya menjadi sebuah alat Tuhan untuk membentuk dua pribadi untuk melayani-Nya melalui pernikahan dan juga keluarganya. Undang-Undang Republik Indonesia No. 1 tahun 1974 pasal 6 mengatur batas minimal usia untuk menikah di mana pernikahan hanya diizinkan jika pria sudah mencapai usia 19 tahun dan pihak wanita sudah mencapai usia 16 tahun. Akan tetapi dari sisi medis dan psikologis, usia tersebut masih terbilang dini untuk menghadapi masalah pada pernikahan. Beberapa penelitian bahkan menunjukkan bahwa pernikahan dini di usia remaja lebih berisiko untuk berujung pada perceraian. Pemerintah tentunya sudah menghitung segala dampak baik positif maupun negatif dari pembatasan angka usia untuk memasuki jenjang pernikahan atau perkawinan tersebut. Suarni mengatakan, sikap etika Kristen terhadap pernikahan dini, etika Kristen berbicara tentang hal-hal yang dikehendaki Allah, itulah yang baik. Etika Kristen didasarkan pada perintah-perintah Allah yang bersifat umum (Roma 1:19-20), dan khusus tahu akan kehendak-Nya, dan oleh karena diajarkan di dalam hukum Taurat, untuk dapat mengetahui mana yang baik dan mana yang tidak. Maka secara etis pernikahan dini tidak diperbolehkan atau ditolak, dengan alasan karena anak di usia yang muda menikah akan memikul tanggung jawab yang sangat besar dalam keluarga misalnya mencari nafkah dan bertanggung jawab untuk menjadi orangtua. ${ }^{35}$

Jika pernikahan dini dipaksakan, maka lebih banyak kecenderungan dampak negatifnya dari pada dampak positifnya. Alkitab mengarahkan pernikahan Kristen adalah pernikahan yang bahagia dan penuh dengan cinta sampai maut memisahkan padangan suami istri tersebut. Jika terjadi pernikahan dini maka tentunya pasangan suami istri muda/dini tersebut kehilangan kesempatan untuk memperoleh pendidikan yang layak. Dimana

${ }^{34}$ Azman Arsyad, “Tren Media Sosial Terhadap Pengaruh Tingginya Perceraian

Di Kabupaten Pangkep. | Arsyad | Jurnal Al-Qadau: Peradilan Dan Hukum Keluarga Islam," AlQadau 7, no. 1 (2020): 90.

35 Suarni, “TINJAUAN TERHADAP PROBLEMATIKA PERNIKAHAN

DINIBERDASARKAN ETIKA KRISTEN DI GEREJA KEMAHINJIL INDONESIA LONG BUANG KALIMANTAN UTARA" (SEKOLAH TINGGI THEOLOGIA JAFFRAY, 2016). 
pendidikan yang layak merupakan salah satu modal untuk menikmati kehidupan yang lebih baik. Kejadian 2:24 memberikan penjelasan bahwa sorang laki-laki akan meninggalkan ayah dan ibunya untuk bersatu dengan istrinya. Di sini tersirat batasan yang menunjukkan kedewasaan untuk menikah. Yaitu "meninggalkan ayah dan ibunya" artinya mereka harus mandiri dalam segala hal yang berkaitan dengan kelangsungan perkawinan/keluarga yang dibentuknya. Disamping itu menikah diusia dini menyimpan potensi-potensi masalah yang besar antara lain: resiko penyakit seksual, resiko kekerasan seksual, resiko pada masa kehamilan dan pada msa melahirkan, resiko psikologis dan resiko-resiko lainnya. Pernikahan Kristen diharapkan terhindar dari segala masalah dan resiko tersebut.

Dari penjelasan-penjelasan di atas, maka dapat peneliti memberikan beberapa alasan yang ditemukan di dalam Alkitab yang menentang terjadinya perceraian apapun yang menjadi faktor penyebabnya. Pandangan Alkitab terhadap perceraian sudah sangat nyata yaitu: pertama, perceraian adalah perbuatan dosa. Stevanus mengatakan, bahwa Tuhan Allahlah yang merancang/membentuk sebuah pernikahan dan memberkatinya. Dalam pada itu, Ia tidak punya rancangan perceraian atas apa yang telah dibentuk dan diberkati-Nya itu. Jika manusia merusak apa yang dibentuk dan dipersatukan oleh Allah, maka itu adalah perbuatan dosa. Perceraian adalah pelanggaran terhadap rancangan yang indah dari Tuhan tentang pernikahan. ${ }^{36}$

Kedua, perceraian melukai hati Tuhan. Mal. 2:16 menuliskan bahwa Allah membenci perceraian. Lodewyck menjelaskan bahwa alasan untuk tidak bercerai adalah karena pernikahan adalah merupakan lembaga yang dirancang oleh Allah sendiri. Dan menurut Markus 10:9, apa yang telah dipersatukan Allah tidak boleh dipisahkan oleh manusia. Tindakan atau pilihan untuk bercerai adalah perbuatan yang melukai hati Tuhan. Orang yang melakukan perceraian, mengerjakan perbuatan yang dibenci oleh Allah. Merusak apa yang telah dipersatukan oleh Allah sendiri. Perceraian adalah pelanggaran terhadap perintah Tuhan. ${ }^{37}$

Ketiga, Tuhan tidak merancang dan menyetujui perceraian. Tuhan Yesus mengatakan bahwa sesungguhnya perceraian dari semula tidak diperbolehkan (Mat 19:1-8). Allah dari semula menciptakan laki-laki dan perempuan. Kemudian mereka dipersatukan dan menjadi satu daging. Jadi dari semula Allah merancang pernikahan bukan untuk bercerai.

Keempat, perintah Tuhan untuk saling mengasihi. Maia mengatakan Yohanes berbicara tentang tanda/bukti bahwa kita benar-benar mangasihi Allah, ialah perbuatan kasih terhadap sesama. Allah sangat jelas mengasihi kita. Ia memberikan alam semesta kepada manusia bahkan AnakNya adalah bukti kasihNya. Itu sebabnya "jikalau Allah sedemikian mengasihi kita, maka haruslah kita juga saling mengasihi" (1 Yoh 4:11), tentu bukan hanya dengan perkataan atau dengan lidah, melainkan dengan perbuatan dan dalam kebenaran" (3:18). Kasih yang dinyatakan dalam perbuatan adalah sikap pokok hidup orang beriman. ${ }^{38}$ Perceraian bukanlah perbuatan kasih. Perceraian adalah perbuatan yang saling melukai. Biasanya diawali dengan pertengkaran, saling membuka aib, menjelekkan pasangan masing-masing, kemudian diakhiri dengan perceraian. Perceraian juga melukai hati anak-anak dan keluarga kedua belah pihak. Sulit untuk melihat kasih di dalam sebuah perceraian.

${ }^{36}$ Kalis Stevanus, “Tanggapan Gereja Terhadap Perceraian Dan Pernikahan Kembali,” Kurios 02, no. 1 (2018).

37 Jefry Lodewyck, “Sikap Etis Kristen Terhadap Perceraian Menurut Markus 10:9," Missio Ecclesiae 8, no. 2 (2019): 100.

38 Pe José Maia, "Iman, Harapan Dan Kasih Merupakan Kabajikan Utama Hidup Kristiani," JUMPA 07, no. XX (2019). 


\section{Tanggapan Gereja Terhadap Faktor-Faktor Pemicu Perceraian}

Gereja tidak bisa menutup mata terhadap perceraian yang terjadi. Perceraian yang dimaksud adalah perceraian baik di dalam jemaat maupun di luar jemaat. Hadiwardoyo lebih lanjut mengatakan, sungguh amat memprihatinkan, bahwa lembaga perkawinan yang suci itu, kini kurang dihargai. Lewat drama, roman, novel, film, radio, bahkan publikasi ilmiah, kesucian perkawinan direndahkan, antara lain dengan memuji perceraian dan perzinahan. ${ }^{39}$ Perkawinan adalah suatu persekutuan hidup antara suami dan istri. Suami dan istri yang telah mengambil keputusan untuk menghubungkan diri dalam ikatan perkawinan, bahwa hidup mereka mulai dari nikah mereka diteguhkan dan diberkati oleh gereja merupakan suatu "persekutuan hidup." Perkawinan sebagai suatu persekutuan hidup tidak otomatis terjadi. Ia harus diperjuangkan. Ia harus dibentuk, dipelihara dan dibina: dibentuk, dipelihara dan dibina bersama-sama oleh suami dan isteri. Salah satu syarat yang paling penting untuk itu ialah keterbukaan. Suami dan isteri yang taat pada kehendak Allah dan yang karena itu berusaha untuk membuat perkawinan mereka menjadi suatu persekutuan-hidup yang lestari, harus bersifat terbuka seorang terhadap yang lain. Disinilah peran gereja untuk mendewasakan umatNya agar memiliki pandangan yang Alkitabiah tentang pernikahan atau rumah tangga. Pada saat yang sama tidak boleh melupakan kewajibannya untuk mewartakan kepada dunia akan kesakralan pernikahan/perkawinan/rumah tangga. Agar setiap orang mempunyai rasa hormat yang tinggi terhadap pernikhana/perkawinan/rumah tangga. Sebab apa yang telah dipersatukan oleh Allah, tidak boleh diceraikan manusia.

Para tokoh gereja memiliki pandangan yang hampir sama tentang pernikahan. Sabdono berpendapat yang sama, bahwa pernikahan adalah gagasan Allah. Allah yang menentukannya sejak semula bahwa laki-laki harus dipersatukan dengan perempuan. Pernikahan sama sekali bukan prakarsa manusia, tetapi prakarsa Allah sendiri. Karena itu, pernikahan harus diakui dan diterima sebagai suatu karunia atau anugerah Allah atas manusia. ${ }^{40}$ Sementara itu Keuskupan Agung Jakarta mengatakan, perkawinan tak terpisahkan (perceraian tidak diperbolehkan) karena alasan-alasan berikut: karena esensi atau inti dari cinta kasih adalah saling memberi diri tanpa syarat; karena pernikahan ini merupakan gambaran kesetiaan tanpa syarat dari Allah terhadap ciptaanNya; karena ini merupakan gambaran pengabdian Kristus kepada GerejaNya, bahkan sampai mati di kayu salib. Selanjutnya Kusumawanta mengatakan, gereja Katolik melarang perceraian karena: 1) Tuhan Yesus telah mengangkat perkawinan dari tingkat kodrati ke adikodrati, dengan menjadikannya sakramen. Karena itu, ikatan sakramen perkawinan yang diikuti oleh hubungan suami istri yang pertama, tidak dapat diceraikan, kecuali oleh kematian salah satu pihak. "Apa yang dipersatukan Allah, tidak boleh diceraikan manusia" (Mat 19:6). 2) Tuhan Yesus secara tegas melarang pemutusan ikatan perkawinan, dengan berkata, "Setiap orang yang menceraikan isterinya, lalu kawin dengan perempuan lain, ia berbuat zinah; dan barangsiapa kawin dengan perempuan yang diceraikan suaminya, ia berbuat zinah" (Luk 16:18). "Barangsiapa menceraikan isterinya lalu kawin dengan perempuan lain, ia hidup dalam perzinahan terhadap isterinya itu. Jika isteri menceraikan suaminya dan kawin dengan laki-laki lain, ia berbuat zinah" (Mrk 10:11-12).41

Sudah seharusnya setiap orang memiliki penghormatan yang tinggi terhadap sebuah pernikahan, sebab pernikahan adalah gagasan Allah sendiri. Pernikahan pada awalnya adalah inisiatif Allah dan bukan manusia. Keinginan manusia untuk membentuk sebuah keluarga

\footnotetext{
${ }^{39}$ Hadi Widoyo, Maranatha, and Ndapamuri, "KUASA ALLAH DALAM ELIADAM IMPLIKASINYA BAGI UMAT TUHAN PADA MASA KINI."

${ }^{40}$ Erastus Sabdoono, Perceraian (Jakarta: Rehobot Literature, 2018).

${ }^{41}$ Kusumawanta, "Apakah Perceraian, Dan Bagaimana Sikap Gereja Katolik Terhadap Perceraian?," Katilisitas.Org.
} 
bukanlah semata-mata keinginannya sendiri, melainkan juga merupakan keinginan Allah. Pernikahan adalah bagian dari rencana Allah bagi umat manusia. Allahlah yang membentuk pernikahan dan memberkatinya. Tetapi Ia tidak punya rancangan perceraian atas apa yang telah dibentuk dan diberkati-Nya. Dalam menghadapi menyelesaikan setiap konflik, suami istri harus selalu mengingat kepada Allah sebagai Sang perancang pernikahan. Dapat dipastikan bahwa pernikahan yang dirancang oleh Allah adalah pernikahan seumur hidup. Alasannya karena Tuhan sendiri membenci perceraian. Perceraian tidak hanya selesai pada bubarnya ikatan suami istri tetapi akan berlanjut kepada masalah-masalah berikut yang mengikutinya. Masalah tersebut adalah konflik psikoligis yang dialami oleh anak-anak yang mereka lahirkan, putusnya atau terganggunya hubungan silaturahmi antara keluarga kedua belah pihak. Belum lagi potensi masalah berikutnya tentang pembagian harta. Gereja tentu tidak ingin melihat masalah yang berantai ini terjadi dan menimpa umat-umat gereja. Dengan demikian, gereja harus tegas terhadap warganya dalam hal perceraian. Gereja harus berjuang sekuat tenaga untuk mencegah terjadinya perceraian. Di dalam dan oleh kasih Kristus, setiap konflik dalam pernikahan dapat diselesaikan. Di dalam dan oleh Kristus, perceraian atau bubarnya sebuah ikatan pernikahan/perkawinan dapat dihindari. Dengan demikian masalah berantai tentang bubarnya perkawinan/pernikahan dapat diminimalisir atau ditiadakan.

\section{Implikasi}

Penulis berharap bahwa hasil penelitian ini dapat memberikan manfaat baik kepada jemaat dan para pelayan gereja dalam hal ini diaken atau pendeta akan tanggapan Alkitab tentang perceraian. Bahwa pernikahan adalah lembaga suci yang dibentuk oleh Allah sendiri yang tidak boleh dirusak atau dibatalkan oleh siapapun. Bahwa Allah tidak pernah merencanakan sebuah perkawinan akan berkahir dengan perceraian kecuali oleh maut. Kiranya tulisan ini bisa memberi kontribusi kepada pendeta, penatua dan guru Agama Kristen dalam meningkatkan kualitas pengajarannya berdasarkan Alkitab. Kiranya hasil penelitian ini dapat menolong gereja dan lembaga-lembaga pendidikan dapat memberikan pendidikan serta konseling pastoral bagi pasangan pra nikah atau yang sudah menikah tentang tanggapan Alkitab terhadap faktor-faktor yang menjadi pemicu terjadinya sebuah perceraian, kemudian dapat mengambil langkah antisipatif demi mencegah terjadinya sebuah perceraian.

\section{Rekomendasi untuk Penelitian Lanjutan}

Penulis menyadarai bahwa hasil penelitian ini masih jauh dari sempurna. Dengan demikian penulis sangat terbuka untuk semua masukan dan informasi yang bisa semakin memperkaya penelitian ini. Dan penulis berharap bahwa apa yang disajikan dalam penulisan ini dapat menjadi dasar dan membantu untuk penelitian lebih lanjut tentang tanggapan Alkitab dan gereja terhadap faktor-faktor perceraian. Kemudian, kiranya tulisan ini dapat menjadi referensi bagi penulisan-penulisan berikutnya dari peneliti yang membahas topik ini.

\section{Kesimpulan}

Berdasarkan kajian di atas, dapat disimpulkan: pertama, Alkitab menentang perceraian. Allah membenci perceraian (Maleakhi 2:16) maka setiap orang yang melakukan perceraian sesungguhnya mereka sedang melakukan apa yang dibenci oleh Allah. Orangorang kebencian Allah, tidak akan mungkin mengalami berkat-berkat di dalam hidupnya. Setiap pasangan suami istri harus mendasarkan dan menyelesaikan setiap masalah dalam keluarganya sesuai dengan pandangan Alkitab, pandangan Kristus. Di dalam Kristus dan kasihNya, tidak satupun masalah yang tidak dapat diselesaikan. Di dalam kasih Kristus semuanya pasti bisa diatasi/diselesaikan (Kolose 3:14). Kedua, gereja terpanggil untuk 
membawa suara kebenaran. Kebenaran yang didapat dari Firman Tuhan/Injil/Alkitab. Gereja tidak boleh kompromi dengan perceraian. Gereja harus mendewasakan warganya agar memiliki pandangan yang benar terhadap sebuah ikatan pernikahan/perkawinan. Sebab perkawinan/pernikahan bukan hanya sekedar ikatan antara pria dan wanita, tetapi juga melambangkan hubungan Kristus dan jemaatNya. Gereja harus memiliki pola pembinaan pranikah dan juga penanganan-penanganan terhadap masalah-masalah yang timbul dalam pernikahan/perkawinan.

\section{Rujukan}

Antonius, Seri. "Pernikahan Kristen Dalam Perspektif Firman Tuhan." Jurnal Pionir LPPM Universitas Asahan 6, no. 2 (2020).

Arsyad, Azman. "Tren Media Sosial Terhadap Pengaruh Tingginya Perceraian Di Kabupaten Pangkep. | Arsyad | Jurnal Al-Qadau: Peradilan Dan Hukum Keluarga Islam." Al-Qadau 7, no. 1 (2020): 90.

Barclay, William. Pemahaman Alkitab Setiap Hari: Kitab Roma. Jakarta: BPK Gunung Mulia, 2011. Borrong, Robert P. Etika Seksual Kontemporer. Bandung: Ink Media, 2006.

Christanday, Alexander. Komunikasi Kristen. Yogyakarta: Yayasan Andi Offsett, 2015.

Christanday, Andreas. Komunikasi Dalam Keluarga Kristen. Yogyakarta: Andi Offsett, 2015.

Dwi Hadya Jayani. "Ramai-Ruu-Ketahanan-Keluarga-Berapa-Angka-Perceraian-DiIndonesia." https://databoks.katadata.co.id (2018).

Freddy Pieloor. Money, Love and Marriage. Jakarta: PT Elex Media Kamputindo, 2013.

Gunawan T. Samuel. "Artikel Sabda.Org/Perceraian Dan Pernikahan Kembali." artikel sabda.org/perceraian dan pernikahan kembali (2017).

Hadi Widoyo, Christian Ade Maranatha, and Yohanis Ndapamuri. "KUASA ALLAH DALAM ELIADAM IMPLIKASINYA BAGI UMAT TUHAN PADA MASA KINI." QUAERENS Vol.2, no. 1 (2020): 24.

Harjianto, Harjianto, and Roudhotul Jannah. “Identifikasi Faktor Penyebab Perceraian Sebagai Dasar Konsep Pendidikan Pranikah Di Kabupaten Banyuwangi." Jurnal Ilmiah Universitas Batanghari Jambi 19, no. 1 (2019): 35.

Hasanah, Uswatun. "Pengaruh Perkawinan Usia Muda Pada Tingkat Perceraian Dini (Studi Kasus Pengadilan Agama Kisaran)." Journal of Science and Social Research 1, no. February (2018): 13-18.

Hidayat, Rofiq. "Melihat-Tren-Perceraian-Dan-Dominasi-Penyebabnya." hukumonline 4 (2018).

J.Verkuyl. Etika Kristen: Seksuil. Jakarta: BPK Gunung Mulia, 1989.

Juliansyah Noor. Metode Penelitian. Jakarta: Kencana Prenada Media Group, 2012.

Kalis Stevanus. "Tanggapan Gereja Terhadap Perceraian Dan Pernikahan Kembali." Kurios 02, no. 1 (2018).

Kusumawanta. “Apakah Perceraian, Dan Bagaimana Sikap Gereja Katolik Terhadap Perceraian?" Katilisitas.Org.

LaHaye, Tim. Kebahagiaan Pernikahan Kristen. Jakarta: BPK Gunung Mulia, 2011.

Lerebulan, Aloysius. Keluarga Kristiani, Antara Idealisme Dan Tantangan. Yogyakarta: Kanisius, 2016.

Lodewyck, Jefry. "Sikap Etis Kristen Terhadap Perceraian Menurut Markus 10:9." Missio Ecclesiae 8, no. 2 (2019): 100.

Maia, Pe José. "Iman, Harapan Dan Kasih Merupakan Kabajikan Utama Hidup Kristiani." JUMPA 07, no. XX (2019).

Maiaweng, Peniel C.D. “Perceraian Dan Pernikahan Kembali.” Jurnal Jaffray 15, no. 1 (2017): 97. 
Manurung, M.R. Manajemen Keluarga. Bandung: Indonesia Publishing House, 1995.

Matondang, Armansyah. "Faktor-Faktor Yang Mengakibatkan Perceraian Dalam Perkawinan." JPPUMA: Jurnal Ilmu Pemerintahan dan Sosial Politik UMA (Journal of Governance and Political Social UMA) 2, no. 2 (2014): 141-150.

Matthew Henry. Tafsiran Matthew Henry Injil Matius 15-28. Surabaya: Momentum Press, 2008. Mulyana, Dedy. Metode Penelitian. Bandung: Rosdakarya, 2002.

Obaja Tanto Setiawan. Dahsyatnya Visi. Yogyakarta: Yayasan Andi Offsett, 2009.

Sabdoono, Erastus. Perceraian. Jakarta: Rehobot Literature, 2018.

Salsadilla, RA. Mengatasi Masalah Dengan Mangatasi Masalah. Jakarta: CV Pranata Widya Sejahtera, 2020.

Septiningsih, Dyah Siti, and Nur'aeni. "Education for Family Wellness": Sebuah Upaya Prevensi Terjadinya Konflik Perkawinan, Kekerasan Dalam Rumah Tangga (Kdrt) Dan Perceraian." Prosiding Seminar Nasional Penelitian dan PKM Sosial, Ekonomi dan Humaniora Vol 4 (2014).

Steven Anugerah Jaya Ndruru. "Pernikahan Kudus, KDRT Dan Perceraian Dalam Gereja Masa Kini." OSFPREPRINTS 1 (2020).

Suarni. "TINJAUAN TERHADAP PROBLEMATIKA PERNIKAHAN DINIBERDASARKAN ETIKA KRISTEN DI GEREJA KEMAHINJIL INDONESIA LONG BUANG KALIMANTAN UTARA." SEKOLAH TINGGI THEOLOGIA JAFFRAY, 2016.

Tambunan, E. H. Mengatasi Masalah Keluarga. Bandung: Indonesia Publishing House, 1998.

Trisna, Jonathan A. Pernikahan Kristen Suatu Usaha Dalam Kristus. Bandung: Kalam Hidup, 1987.

Unipagow. "Faktor-Faktor Dan Dampak Perceraian.Htm." Unipagow.blog.spot.co.id (2013).

Zaluchu, Sonny Eli. "Strategi Penelitian Kualitatif Dan Kuantitatif Di Dalam Penelitian Agama." Evangelikal: Jurnal Teologi Injili dan Pembinaan Warga Jemaat 4, no. 1 (2020): 28. 